\title{
RESPONSE OF LACTATING BUFFALOES TO FIBROLYTIC ENZYMES AND THEIR INFLUENCE ON MILK AND CHEESE PROPERTIES
}

\author{
A.M. Kholif, Jihan M. Kasem, Hala M. Bayoumi and A.H. Zaghlool \\ Dairy Science Department, National Research Centre, Dokki, Giza, Egypt.
}

Corresponding author: am kholif2000@yahoo.co.uk

(Received 11/10/2016, Accepted 15/11/2016)

\section{SUMMARY}

$\mathrm{T}$ The task of this research is assessing the action of two different fibrolytic enzymes supplementation on milk yield and cheese properties by lactating buffaloes. Three sets had been worked on, everyone had three animals of lactating buffaloes after 3 months of parturition, with 30 days interval. The first one was fed on $50 \%$ concentrate feed mixture (CFM), 30\% corn silage, $20 \%$ rice straw served as control (C). The second and third sets were fed on the same control ration supplemented with Asperozym or Tomoko ${ }^{\circledR}$ at $2 \mathrm{~g} \mathrm{~kg}^{-1} \mathrm{DM}$ served as $\left(\mathrm{T}_{1}\right.$ and $\left.\mathrm{T}_{2}\right)$. These three different types of lactating milk had been used to manufacture of white soft cheese (WSC). Both of milk and WSC samples were analyzed for some chemical parameters (milk \& cheese yield, pH, total solids, total protein, ash contents, free fatty acids and amino acids profile). Furthermore, sensory evaluation of WSC samples had been taken in consideration. Data revealed that supplementation with Asperozym or Tomoko ${ }^{\circledR}$ enzymes had significantly $(\mathrm{P}<0.05)$ increased $4 \%$ fat-corrected milk and cheese yield. On the other hand, WSC samples with both of fibrolytic enzymes were significantly $(\mathrm{P}<0.05)$ rose in short and long chain fatty acids, while Asperozym cheese samples only were lower in medium chain fatty acids compared to control. Regarding to other chemical composition parameters (TN, TN/SN, TVFAs, tyrosine, tryptophan and pH values) of resulted cheese during storage period, all these parameters were significantly $(\mathrm{P}<0.05)$ boosted after 15 days of storage. For amino acids profile, Asrozym and Tomoko were lowered $(\mathrm{P}<0.05)$ histidine, threonine, isoleucine, leucine, glycine, alanine and proline but Tomoko enzyme raised $(\mathrm{P}<0.05)$ valine, methionine, phenylalanine and serine. Supplementation of fibrolytic enzymes did not manipulate $(\mathrm{P}>0.05)$ sensory evaluation of WSC samples. Supplementation of fibrolytic enzymes on buffalo's diet did not significantly affect lactation performance except $4 \%$ fat corrected milk, fatty acids and amino acids profile in WSC. Therefore, further study must be conducted on the impact of fibrolytic enzymes on different lactating animals.

Keywords: Fibrolytic enzymes, milk yield, white soft cheese, fatty acids, amino acids profile.

\section{INTRODUCTION}

Rising requirements for milk and chip prices in dairy industry requests incorporated projections to raise production performance. One simple direction of increment production capacity would be improve nutrients availability of feedstuffs. Ruminants derive a large quantity of nutritional deficiencies (energy) from the liberation of plants cell wall polysaccharides. The primarily constituent of plants cell wall is cellulose and it is also known to be the most abundant polysaccharide in nature. Most of these complex polysaccharides are bound to lignin, tannin and pectin rendering it inaccessible for digestion. Consequently, one of the most important plan is motivating the digestion of these lingo-cellulosic materials in ruminant feeds. Likewise, using of fibrolytic enzymes as a driver for specific digestive and metabolic process in rumen may be maximize natural digestive processes and ameliorate nutrient availability (Bielecki et al., 2005; Natsir, 2012 and Msimango et al. 2016)

Supplementation of animal diets with fibrolytic enzymes had been recommended by a lot of investigators to improve feed digestion and animal performance through enhancing fiber degradation in vitro (Gado et al. 2007; Rodrigues et al. 2008 and Azzaz et al. 2012) and in situ (Tricarico. et al. 2005 ; Krueger and Adesogan ; 2008). There were some of contrasting studies of using fibrolytic enzymes. 


\section{Kholif et al.}

Gado et al. (2009) and Kholif et al. (2010) showed that utilizing fibrolytic enzyme supplements in dairy animal's diets can progress milk production, while Bowman et al. (2002) and Reddish and Kung (2007) had converse opinion that there was no conclusion had been found on milk production. Reasons for the discrepancy between these opinions are due to factors like lactation duration, dietary components, forage to concentrate proportion, enzyme structure, enzyme level and method of application.

Addition of fibrolytic enzymes to ration increased feed absorption, this is because raise palatability as a result of sugar released by pre-ingestive fiber hydrolysis in diet (Khattab et al. 2011 and Salem et al. 2013). However, post-ingestive enzyme effects, such as increased digestion rate and extent of digestion, may raise hydrolytic performance in the rumen to reduce gut fill and enhance feed intake (Krueger and Adesogan 2008)

Morgavi et al. (2000); Nsereko et al. (2000) and Elghandour et al. (2015) illustrated that direct fed enzymes can also consolidate microbial colonization of feed by raising numbers of ruminal fibrolytic microbes. While, Giraldo et al. (2008), Yang et al. (1999) and Nsereko et al. (2002) stated that this caused increment rate of degradation of fiber in the rumen, rumen microbial protein synthesis and for rumen digestibility.

On the other hand, addition of exogenous enzymes to ruminant diet had favorable effects in cows and growing cattle (Khattab et al. 2011 and Salem et al. 2013) confirmed results had clarified by (Stella et al. 2007; Gado et al. 2009; and Kholif and Azaz 2014) when dairy cows fed forage treated with fibrolytic enzymes additive, they consumed more feed and produced 5-25\% more milk, improved the energy balance of transition dairy cows and increased milk production in small ruminants.

A merchant exogenous enzyme blend (ZADO®), designed by anaerobic bacterium, has been presented of recovering daily gain (Valdes et al. 2015 ) as well as milk yield (Gado et al. 2009; and Khattab et al. 2011)

Law, (1999) and Fox et al. (2000) manifested that when milk; skimmed or cream or mixture of them coagulated with rennet enzymes, produced cheese whether fresh or matured product. We can also produce cheese rom milk of cows, buffaloes, sheep, goats and camels or mixture of two of these (Herrington 2000).

White soft cheese is one of the most principle dairy products consumed regularly on Egyptian table. These cheeses differ in their chemical composition and sensory characteristics, due to milk structure, production process, microbial flora, sort of package, microbial activity during ripening and mature state (Mustafa et al. 2013).

The target of this study is making a comparative research of the influence of adding two different types of fibrolytic enzymes; one is Egyptian like Asperozym and the other is imported from Japan like Tomoko $^{\circledR}$ to rations of lactating buffaloes on milk yield and its composition. Applied both of produced milk on manufacture of white soft cheese and analyzed these chesses for their chemical composition, fatty acids \& amino acids profile and sensory evaluation.

\section{MATERIALS AND METHODS}

\section{Enzymes sources}

Tomoko ${ }^{\circledR}$ : A commercial enzyme of Biogenkoji Research Institute - Japan. The enzyme product was made from Aspergillus Awamori (3million cells/g) including $1000 \mathrm{unit}^{-1}$ of acidic protease, $30 \mathrm{unit}^{-}$ ${ }^{1}$ of pectinase, 25 unit $\mathrm{g}^{-1}$ of xylanase, 20 unit $\mathrm{g}^{-1}$ of $\alpha$-amylase, 10 unit $\mathrm{g}^{-1}$ of phytase, 5 unit $^{-1}$ of glucoamylase and 4 unit $\mathrm{g}^{-1}$ of cellulase.

Asperozym: It had been produced laboratory from Aspergillus niger; in Dairy Science Department, National Research Centre. Each gram contains 30 units of pectinase and 4 unit of cellulase.

Enzymes assay: The pectinase and carboxymethyl-cellulase activities (CMC) for resultant crude enzyme extract (Asperozym) and commercial enzymes source (Tomoko ${ }^{\circledR}$ ) were determined according to Mandels et al. (1974) One unit of pectinase activity was defined as the amount of enzyme that produced one $\mu$ mole of D-galacturonic acid per minute at $40^{\circ} \mathrm{C}$ and $\mathrm{pH} 5.0$ (Soares et al ; 1999) while One cellulase unit was defined as the amount of enzyme that liberates reducing sugar at the rate of $1 \mu \mathrm{mol} \mathrm{mL}^{-}$ ${ }^{1} \mathrm{~min}^{-1}$ under assay condition (Miller, 1972) 
Experimental animals: Nine mid-lactation buffaloes at third to fifth seasons of lactation and weighed on average $(620 \mathrm{~kg})$ were used in the present study. Buffaloes were randomly divided after 3 months of parturition into three groups of three animals each using $3 \times 3$ Latin square design with 30 days interval periods. Milk and feed samples were taken at the end of each period.

Experimental rations: Buffaloes were individually fed 3\% of body weight changed continuously according to animal weight changes. The first group of buffaloes were fed on $50 \%$ concentrate feed mixture (CFM), 30\% corn silage , 20\% rice straw (control ration). The second group was fed control ration supplemented with Asperozym at $2 \mathrm{~g} \mathrm{~kg}^{-1} \mathrm{DM}\left(\mathrm{T}_{1}\right)$, while the third group was fed control ration supplemented with Tomoko ${ }^{\circledast}$ at $2 \mathrm{~g} \mathrm{~kg}^{-1} \mathrm{DM}$. $\left(\mathrm{T}_{2}\right)$. The concentrate feed mixture consisted of $45 \%$ yellow corn, 20\% soybean meal , 15\% wheat bran, 15\% Distillers Dried Grains with Soluble (DDGS) 3\% limestone, $1 \%$ minerals and $1 \% \mathrm{NaCl}$. Chemical compositions of CFM, corn silage, and rice straw are shown in Table (1).

\section{Feeding management:}

The concentrate feed mixture was offered twice daily at 8.00 a.m. and 4:00 p.m., corn silage was offered at 9:00 a.m., while rice straw was offered at 5:00 p.m. The enzymes were introduced twice daily to each animal of second and third group with the concentrate feed mixture. Fresh water was available to the animals all the time.

\section{Feed analysis:}

Feedstuffs samples were analyzed according to .AOAC (1995) methods to Determine Dry Matter (DM), Crude Protein (CP), Ether Extract (EE), Crude Fiber (CF) and ash contents. Organic matter (OM) and Nitrogen Free Extract (NFE) contents were calculated by difference. The Neutral Detergent Fiber (NDF), Acid Detergent Fiber (ADF) and Acid Detergent Lignin (ADL) contents were determined using the methods described by Van Soest et al. (1991).

Table (1): Chemical composition of feed ingredients (DM basis).

\begin{tabular}{lccc}
\hline Item & CFM & Corn silage & Rice straw \\
\hline (DM)Dry Matter & 91.25 & 93.50 & 95.00 \\
Chemical composition & & & \\
(OM)Organic Matter & 89.50 & 92.33 & 88.60 \\
Crude Protein (CP) & 14.05 & 8.11 & 2.86 \\
Ether Extract (EE) & 6.55 & 3.45 & 1.88 \\
Crude Fiber (CF) & 5.13 & 23.55 & 29.26 \\
Nitrogen Free Extract (NFE) & 63.77 & 57.22 & 54.60 \\
Ash & 10.50 & 7.67 & 11.40 \\
\% Cell wall constituents & & & \\
(NDF)Neutral Detergent Fiber & 30.13 & 52.00 & 66.81 \\
Acid Detergent Fiber (ADF) & 11.91 & 40.95 & 52.99 \\
Acid Detergent Lignin (ADL) & 4.12 & 5.71 & 12.95 \\
Hemicellulose & 18.22 & 11.05 & 13.82 \\
Cellulose & 7.79 & 35.24 & 40.04 \\
\hline
\end{tabular}

Hemicellulose $=N D F-A D F$, Cellulose $=A D F-A D L, C F M=$ Concentrate feed mixture.

Each value is a mean of three samples.

Sampling and analysis of milk: Buffaloes were machine milked twice a day at 7:00 am and 7:00 pm. Milk samples were taken after the end of adaptation period during the last three days of each period up to the end of experimental period. Samples of milk were collected immediately from each animal after morning and evening milking and milk yield was recorded. The sample of each animal represented a mixed sample of constant percentage of the evening and morning yield. Milk samples were analyzed for 


\section{Kholif et al.}

total solids, fat, true protein and lactose by infrared spectrophotometry (Foss 120 Milko-Scan, Foss Q3 183 Electric, Hillerød, Denmark) according to AOAC (1995) procedures. Solids-not-fat (SNF) was calculated. Fat corrected milk ( $4 \%$ fat) was calculated by using the following equation:

$\mathrm{FCM}=0.4 \mathrm{M}+15 \mathrm{~F}$

Where: $(\mathrm{M})$ is milk yield $(\mathrm{g})$ and $(\mathrm{F})$ is fat yield $(\mathrm{g})$.

Composite milk sample per buffalo and frozen at $-20^{\circ} \mathrm{C}$ until analyzed for soft cheese manufacture. Milk samples were stored at $4^{\circ} \mathrm{C}$ with a preservative (bronopol-B2) until analyzed for total solids, proteins, fat, ash and lactose.

\section{Cheese manufacturing:}

Collected milk from each group was pooled and used for analysis and manufacturing of traditional soft cheese according to Fahmi and Sharara (1950). All milk batches were heated to $75^{\circ} \mathrm{C} / 15 \mathrm{sec}$. and then cooled to $38^{\circ} \mathrm{C}$. Mixed starter cultures $(1 \% \mathrm{w} / \mathrm{w})$ of Lactococcus lactis ssp. lactis and Lactococcus lactis ssp. cremoris (Chr. Hansen's Lab., A/S Copenhagen, Denmark) and salt (4\%w/w) were added to cheese milk, and appropriate amount of rennet was added to achieve coagulation in 120 min. After coagulation, curd was cut and transferred to mould and left to rest overnight at room temperature. Cheese blocks were cut, weighted and analyzed when fresh and after 30 days of cold storage $\left(7 \pm 2^{\circ} \mathrm{C}\right)$.

\section{Chemical analysis:}

Total solids, fat, total protein $(\mathrm{N} \times 6.38)$ and ash content of both milk and soft cheese were determined according to AOAC (2007). Milk lactose contents were calculated. $\mathrm{pH}$ values were measured using a digital pH meter (HANNA, instrument, Italy). Cheese yield was calculated as the weight of finished cheese divided by the weight of milk used.

\section{Fatty acids profile:}

\section{Conditions of GC analysis:}

Type of GC: Perkin Elmer Auto System XL.

Equipped with flame ionization detector (FID).

- Fused silica capillary column ZB-wax (60 mx0.32 mm i.d).

- Oven temperature was maintained initially at $50{ }^{\circ} \mathrm{C}$, hold 2 min and programmed from 50 to $220{ }^{\circ} \mathrm{C}$ at rate of $4{ }^{\circ} \mathrm{C} / \mathrm{min}$, hold at $220{ }^{\circ} \mathrm{C}$ for $30 \mathrm{~min}$.

Injector temp. $230{ }^{\circ} \mathrm{C}$, Detector temp. $250^{\circ} \mathrm{C}$, Carrier gas: Helium, flow rate $1 \mathrm{ml} / \mathrm{min}$.

\section{Amino acids fractions:}

Procedure: Acid hydrolysis of sample (All amino acids except cystiene \& Tryptophan): A sample corresponding to $40 \mathrm{mg}$ protein was weight into $25 \times 150 \mathrm{~mm}$ hydrolyzed tube. Aliquot $(7.5 \mathrm{ml})$ of $6 \mathrm{~N}$ HCL was added purged with nitrogen for $60 \mathrm{sec}$. and tube was capped immediately. The tubes were placed in $110^{\circ} \mathrm{C}$ oven for $24 \mathrm{hr}$., removed from the oven and allow cooling. The tube contents were quantitatively transferred to $25 \mathrm{ml}$ volumetric flask and completed to volume with HPLC grade water. About $1 \mathrm{ml}$ of the solution was filtered through $0.45 \mathrm{um}$ sample filter.

Amino acid derivatization: Ten micro-liters of the filtered sample in $6 \times 50 \mathrm{~mm}$ tube were placed into drying vessel and dry in Waters Pico-Tag Workstation in 10-15 min at $<50$ millitorr. Aliquot (30 ul) of ready solution (200ul methanol, $200 \mathrm{ul} 0.2 \mathrm{~N}$ sodium acetate and $100 \mathrm{ul}$ triethylamine ) and dry the sample again in the Workstation Aliquot (30ul) of the freshly prepared of the derivatization reagent $(350 \mathrm{ul}$ methanol, 50ul HPLC grade water, 50ul triethylamine and $50 \mathrm{ul}$ phenylisothiocyanate, PITC) to the tube contents and allow to react for $20 \mathrm{~min}$ and dry in the workstation for $15 \mathrm{~min}, 30 \mathrm{ul}$ HPLC grade methanol was added and ready. Add $100 \mathrm{ul}$ of sample diluents to the tube, vortex and transfer to injection vials. The standard amino acids of solution is treated the same as the sample.

HPLC of Amino Acids: The appertain used is Waters, Cooperation, USA with 484 UV/Vis detector and Millenuim Software program as well as Pico-Tag column for amino acids. The analysis was carried out using a gradient of Pico-Tag solvent $\mathrm{A} \& \mathrm{~B}$ at $40^{\circ} \mathrm{C}$ and flow rate $1 \mathrm{ml} / \mathrm{min}$. Detection of the separated Pico-Tag-amino acids at $254 \mathrm{~nm}$ wave length. Before injecting of the sample, the illustrated was calibrated by two injections of the standards.

\section{Sensory evaluation of cheese:}

Cheese samples were judged by a panel taste of 15 staff members of the Dairy Science Department, National Research Centre, Egypt. The cheese was scored for appearance (10 points), body and texture (40 points) and flavor (50 points) as suggested by ADSA (1987). 


\section{Statistical analysis:}

Data obtained from this study were statistically analyzed by SAS (2004). The Duncan's multiple range tests (Duncan, 1955) were used for data of the experiment to test the significance among means.

\section{RESULTS AND DISCUSSION}

\section{Milk yield and its composition:}

It had been observed that no significant differences $(\mathrm{P}>0.05)$ in milk composition, $\mathrm{pH}$ values and milk yield through control and treated sets. Whilst, $4 \%$ fat-corrected milk (FCM) yield was significantly higher with fibrolytic enzymes than control. Boost of Asperozym to lactating buffalo's ration had increased milk production to 6.06 and $4 \%$ fat corrected milk production by $3.74 \%$, when addition of Tomoko ${ }^{\circledR}$ to lactating buffalo's ration increased milk production to 4.65 and $4 \%$ fat corrected milk production within $1.03 \%$ compared with control ration as shown in Table (2). Beauchemin et al,(2004) clarified the response of animal to fibrolytic enzymes according to some factors such as enzyme properties, enzyme rate and animal species. While, Titi (2003) explained that the lack of response on fat and protein concentration is not necessarily a negative consequence of adding fibrolytic enzymes. It might be due to the increased fiber digestibility which reduced the effective neutral detergent fiber (NDF) content of the diet.

Table (2): Buffaloes milk yield and its composition as affected by adding fibrolytic enzymes in diets compared to control.

\begin{tabular}{lcccc}
\hline Item & Control & $\mathrm{T}_{1}$ & $\mathrm{~T}_{2}$ & $\mathrm{SE}$ \\
\hline Milk yield (kg/d) & $7.75^{\mathrm{a}}$ & $8.22^{\mathrm{a}}$ & $8.11^{\mathrm{a}}$ & 0.17 \\
4\% FCM yield & $10.69^{\mathrm{b}}$ & $11.09^{\mathrm{a}}$ & $10.80^{\mathrm{a}}$ & $0.13^{*}$ \\
(kg/d) & $16.87^{\mathrm{a}}$ & $16.39^{\mathrm{a}}$ & $16.48^{\mathrm{a}}$ & 0.21 \\
Total solids \% & $6.53^{\mathrm{a}}$ & $6.33^{\mathrm{a}}$ & $6.21^{\mathrm{a}}$ & 0.19 \\
Fat \% & $10.34^{\mathrm{a}}$ & $10.06^{\mathrm{a}}$ & $10.27^{\mathrm{a}}$ & 0.12 \\
SNF \% & $4.01^{\mathrm{a}}$ & $3.87^{\mathrm{a}}$ & $3.98^{\mathrm{a}}$ & 0.18 \\
Total protein \% & $4.77^{\mathrm{a}}$ & $4.74^{\mathrm{a}}$ & $4.81^{\mathrm{a}}$ & 0.07 \\
Lactose \% & $1.56^{\mathrm{a}}$ & $1.45^{\mathrm{a}}$ & $1.48^{\mathrm{a}}$ & 0.05 \\
Ash \% & $6.51^{\mathrm{a}}$ & $6.43^{\mathrm{a}}$ & $6.48^{\mathrm{a}}$ & 0.04 \\
$\mathrm{pH}$ value &
\end{tabular}

$T_{1}=$ Asperozym , $T_{2}=$ Tomoko, each value is a mean of 27 samples from 9 animals, $S E=$ Standard error.

These outcomes were in line with those acquired by Chen et al. (1995) who found that applied of fibrolytic enzyme mixtures (DigestM ${ }^{\circledR}$, Loveland Industries Inc., Greeley, CO, USA) onto sorghum grain did not promote milk production in Holstein cows. Identical data were stated by Beauchemin et al. (2000) who added non starch poly-saccharide to grains, had been increased total tract digestibility in midlactation cows; but no effect on milk yield was observed. As well, despite of increasing total tract feed digestion with fibrolytic enzymes in diets of Holstein cows, excess in milk production was not detected Bowman et al. (2002). Also, Elwakeel et al. (2007) who deliberated milk production, milk efficiency and production of all milk components, they found no effect had happened when added fibrolytic enzymes to cow's diets in the presence and absence of supplemental yeast. Similar results were obtained by Titi and Lubbadeh (2004) and Khattab et al. (2011) when the enzymes were fed to goats and sheep. Gado et al. (2009) illustrated that 7-15\% higher in milk production of dairy cows fed fibrolytic enzymes was probably due to increase nutrient digestibility and microbial protein synthesis.

Alsersy et al. (2015) showed the enzyme action on the forage structural polysaccharides improved efficiency of microbial protein synthesis, altering the rate of ruminal degradation of structural carbohydrates and the provision of a proper ruminally degradable nitrogen source. Moreover, Valdes et al. (2015) stated that the supplementation of exogenous enzymes (10 g/day), improved their dry matter (DM) and organic matter (OM) digestibility with an affirmative effectiveness on the use of $\mathrm{N}$ and microbial protein synthesis.

In our study, the variation in energy status of lactating animals varied with changing in stage of lactation, and this could probably differ in response to both of fibrolytic enzymes that added to rations. 


\section{Kholif et al.}

The corroboration of this study was found in some researches; Schingoethe et al. (1999) and Beauchemin et al. (2000) who informed that there were positive effect to enzyme-treated forages in early lactation on milk yield and composition, but no response formed in later lactation. Same data were established by Zheng et al. (2000) who noticed that the action of fibrolytic enzymes on milk production were vigorous in early lactation period. However, Knowlton et al. (2002) elucidated that, when cows had been treated with diet supplemented with fibrolytic enzymes; there response appeared in the first 100 day of lactation; but there were no effect noticed in mid-lactation. Based upon the preceding studies, the favorable energy status of our lactating buffaloes was referred to the shortage of restraint to Asperozym and Tomoko ${ }^{\circledR}$ treatment. Therefore, we could noticed that it is practically unattainable to compare different fibrolytic enzymes with different ratios and their influence on different animal species.

\section{Cheese yield:}

Significant improvement $(\mathrm{P}<0.05)$ were observed in cheese yield with fibrolytic enzymes than cheese produced from control (Table 3). Fibrolytic enzymes that added to buffaloes diets had enhanced cheese yield by $16.96 \%$ with Asperozym and $17.74 \%$ with Tomoko than control diet. Moreover, slight decreased $(\mathrm{P}>0.05)$ curdling time was detected in soft cheese produced from fibrolytic enzymes than control. However, $\mathrm{pH}$ values of two different cheese were insignificant $(\mathrm{P}>0.05)$.

Opposite trends were proved by Kholif et al. (2009), with Baladi cows, Kholif et al. (2010) and Kholif et al. (2015) with goats found insignificant differences in soft cheese yield. These conflict results which had been obtained may be due to the animal species used.

Table (3): Yield and curdling time of white soft cheese.

\begin{tabular}{lcccc}
\hline Item & Control & $\mathrm{T}_{1}$ & $\mathrm{~T}_{2}$ & $\mathrm{SE}$ \\
\hline Cheese yield \% & $35.24^{\mathrm{b}}$ & $41.21^{\mathrm{a}}$ & $41.42^{\mathrm{a}}$ & 1.44 \\
pH of cheese & $6.36^{\mathrm{a}}$ & $6.33^{\mathrm{a}}$ & $6.39^{\mathrm{a}}$ & 0.03 \\
Curdling time (min.) & $52.00^{\mathrm{a}}$ & $50.33^{\mathrm{a}}$ & $48.33^{\mathrm{a}}$ & 2.23 \\
\hline
\end{tabular}

$T_{1}=$ Asperozym,$T_{2}=$ Tomoko, Each value is a mean of 9 samples from 9 animals, $S E=$ Standard error.

\section{Cheese composition:}

On the other hand, cheese composition were illustrated in Table (4). As we observed that storage period had been significantly $(\mathrm{P}<0.05)$ influenced in each of total nitrogen $(\mathrm{TN} \%)$, soluble nitrogen (SN\%), S.N/TN\% ratio, total volatile fatty acids (TVFAs), tyrosine, tryptophan and $\mathrm{pH}$ values. These values were higher after 30 days of storage than values at fresh (zero time). $\mathrm{pH}$ values were significantly decreased from $(6.01,6.03$ and 6.02) in fresh samples to $(5.83,5.85$ and 5.89) after 30 days of storage period in control, $\mathrm{T}_{1}$ and $\mathrm{T}_{2}$ samples respectively. Similar findings were obtained by Wistra et al. (1987),

Table (4): Effect of storage period on chemical composition of white soft cheese.

\begin{tabular}{|c|c|c|c|c|c|c|c|c|c|}
\hline \multirow{2}{*}{ Item } & \multicolumn{4}{|c|}{ Zero time } & \multicolumn{4}{|c|}{30 days } & \multirow{2}{*}{ S.E. } \\
\hline & Control & $\mathrm{T}_{1}$ & $\mathrm{~T}_{2}$ & Mean & Control & $\mathrm{T}_{1}$ & $\mathrm{~T}_{2}$ & Mean & \\
\hline Fat \% & $12.61^{\mathrm{a}}$ & $13.12^{\mathrm{a}}$ & $13.22^{\mathrm{a}}$ & $12.98^{\mathrm{a}}$ & $12.58^{\mathrm{a}}$ & $13.31^{\mathrm{a}}$ & $13.41^{\mathrm{a}}$ & $13.10^{\mathrm{a}}$ & 0.28 \\
\hline T.N. $\%$ & $2.61^{\mathrm{b}}$ & $2.63^{\mathrm{b}}$ & $2.63^{\mathrm{b}}$ & $2.62^{\mathrm{b}}$ & $2.75^{\mathrm{a}}$ & $2.76^{\mathrm{a}}$ & $2.77^{\mathrm{a}}$ & $2.76^{\mathrm{a}}$ & $0.03 *$ \\
\hline S.N. \% & $0.31^{\mathrm{a}}$ & $0.32^{\mathrm{a}}$ & $0.33^{\mathrm{a}}$ & $0.32^{\mathrm{a}}$ & $0.45^{\mathrm{a}}$ & $0.46^{\mathrm{a}}$ & $0.47^{\mathrm{a}}$ & $0.46^{\mathrm{a}}$ & 0.07 \\
\hline S.N./T.N. & $0.11^{\mathrm{b}}$ & $0.12^{\mathrm{b}}$ & $0.12^{\mathrm{b}}$ & $0.12^{\mathrm{b}}$ & $0.16^{\mathrm{a}}$ & $0.16^{\mathrm{a}}$ & $0.16^{\mathrm{a}}$ & $0.16^{\mathrm{a}}$ & $0.01 *$ \\
\hline $\begin{array}{l}\text { TVFAs (ml } 0.1 \\
\text { NaoH/100g) }\end{array}$ & $10.91^{\mathrm{b}}$ & $11.73^{\mathrm{b}}$ & $11.81^{\mathrm{b}}$ & $11.48^{\mathrm{b}}$ & $16.14^{\mathrm{a}}$ & $16.92^{\mathrm{a}}$ & $17.03^{\mathrm{a}}$ & $16.70^{\mathrm{a}}$ & $1.38 *$ \\
\hline $\begin{array}{l}\text { Tyrosine } \\
(\mathrm{mg} / 100 \mathrm{~g})\end{array}$ & $4.13^{\mathrm{b}}$ & $4.44^{\mathrm{b}}$ & $4.51^{\mathrm{b}}$ & $4.36^{\mathrm{b}}$ & $38.41^{\mathrm{a}}$ & $38.52^{\mathrm{a}}$ & $39.01^{\mathrm{a}}$ & $38.65^{\mathrm{a}}$ & $2.11 *$ \\
\hline $\begin{array}{l}\text { Tryptophan } \\
\text { (mg/100g) }\end{array}$ & $3.91^{\mathrm{b}}$ & $3.92^{\mathrm{b}}$ & $4.02^{\mathrm{b}}$ & $3.95^{\mathrm{b}}$ & $18.61^{\mathrm{a}}$ & $18.91^{\mathrm{a}}$ & $19.02^{\mathrm{a}}$ & $18.85^{\mathrm{a}}$ & $0.03 *$ \\
\hline $\mathrm{pH}$ & $6.01^{\mathrm{a}}$ & $6.03^{\mathrm{a}}$ & $6.02^{\mathrm{a}}$ & $6.02^{\mathrm{a}}$ & $5.83^{\mathrm{b}}$ & $5.85^{\mathrm{b}}$ & $5.89^{\mathrm{b}}$ & $5.86^{\mathrm{b}}$ & $0.02 *$ \\
\hline T.S. \% & $34.02^{\mathrm{a}}$ & $36.62^{\mathrm{a}}$ & $34.07^{\mathrm{a}}$ & $34.90^{\mathrm{a}}$ & $34.86^{\mathrm{a}}$ & $37.29^{\mathrm{a}}$ & $35.22^{\mathrm{a}}$ & $35.96^{\mathrm{a}}$ & 1.12 \\
\hline
\end{tabular}

and Hamid (2005), who announced that $\mathrm{pH}$ values progressively reduced during storage. The increment in the cheese acidity might be due to the storage temperature, which activated the natural microflora of 
raw milk to stimulate acidity as a result of lactose fermentation which lead to decrease in $\mathrm{pH}$-value. Furthermore, each of TVFAs, tyrosin and tryptophan had remarkable increased after 30 days of storage period. These data were also in consistent with the result of Abdel Razig, (1996), El-Owni and Hamid (2008). The progress in volatile fatty acid probably could be attributed to lipolytic action of organisms on fat contents during ripening (Abdel Razig, 1996). Same trend was found by El Owni and Hamed (2007) who manufactured Gibna Bayda in Zalingei area had high TVFAs values during storage period. While Hayaloglu et al. (2002) mentioned that higher tryptophane and tyrosine contents might be due to high proteolytic activities occurred in the cheese.

\section{Fatty acids profile in cheese:}

Lipolysis is one of the prime biochemical alteration that participate to flavor development during the cheese ripening, together with proteolysis. Analysis of the short and medium-chain FFA profile has been suggested as an indicator for distinguishing cheeses over the ripening period. FFA is the major contributor to the development of the characteristic flavor in some cheese varieties (Fenelon and Guinee, 2000). Table (5) conducted fatty acids profile of different cheese samples. From this table we can recognized that both of fibrolytic enzymes cheese samples had significantly $(\mathrm{P}<0.05)$ raised contents of short (SCFA), long (LCFA) chain fatty acids and saturated fatty acids but they had low content of medium chain fatty acids (MCFA) and unsaturated fatty acids compared to control cheese samples. Whereas, the ratio between saturated FA/unsaturated FA were higher with fibrolytic enzymes than control. A comparable study by Delgado et al. (2009) who found that short, medium and long chain fatty acids were higher in Spanish soft cheese than control after 60 days of storage periods. (Türkoğlu, 2011)

Table (5): Fatty acids profile ( $\mathrm{g} / 100 \mathrm{~g}$ total fatty acids) of different types of white soft cheese samples at the end of experiment.

\begin{tabular}{|c|c|c|c|c|}
\hline Fatty acids & Control & $\mathrm{T}_{1}$ & $\mathrm{~T}_{2}$ & SE \\
\hline $\mathrm{C}_{6.0}$ & $0.51^{\mathrm{a}}$ & $0.21^{\mathrm{a}}$ & $0.19^{\mathrm{a}}$ & 0.17 \\
\hline $\mathrm{C}_{8.0}$ & $0.48^{\mathrm{a}}$ & $0.38^{\mathrm{a}}$ & $0.61^{\mathrm{a}}$ & 0.08 \\
\hline $\mathrm{C}_{10}$ & $1.38^{\mathrm{b}}$ & $2.58^{\mathrm{a}}$ & $2.26^{\mathrm{a}}$ & $0.14 *$ \\
\hline $\mathrm{C}_{12}$ & $2.44^{\mathrm{b}}$ & $2.98^{\mathrm{a}}$ & $2.74^{\mathrm{b}}$ & $0.15^{*}$ \\
\hline $\mathrm{C}_{14.0}$ & $12.57^{\mathrm{a}}$ & $11.80^{\mathrm{a}}$ & $12.31^{\mathrm{a}}$ & 0.28 \\
\hline $\mathrm{C}_{14.1}$ & $0.80^{\mathrm{a}}$ & $0.78^{\mathrm{a}}$ & $0.65^{\mathrm{a}}$ & 0.19 \\
\hline $\mathrm{C}_{15.0}$ & $1.83^{\mathrm{a}}$ & $1.05^{\mathrm{a}}$ & $1.34^{\mathrm{a}}$ & 0.31 \\
\hline $\mathrm{C}_{16.0}$ & $38.10^{\mathrm{a}}$ & $34.27^{\mathrm{b}}$ & $36.14^{\mathrm{ab}}$ & $0.97 *$ \\
\hline $\mathrm{C}_{16.1}$ & $2.48^{\mathrm{a}}$ & $1.78^{\mathrm{a}}$ & $2.03^{\mathrm{a}}$ & 0.37 \\
\hline $\mathrm{C}_{17.0}$ & $0.45^{\mathrm{a}}$ & $0.74^{\mathrm{a}}$ & $0.71^{\mathrm{a}}$ & 0.18 \\
\hline $\mathrm{C}_{17.1}$ & $0.40^{\mathrm{a}}$ & $0.46^{\mathrm{a}}$ & $0.29^{\mathrm{a}}$ & 0.13 \\
\hline $\mathrm{C}_{18.0}$ & $16.35^{\mathrm{b}}$ & $22.53^{\mathrm{a}}$ & $20.07^{\mathrm{a}}$ & $1.22 *$ \\
\hline $\mathrm{C}_{18.19 \mathrm{cis}}$ & $16.38^{\mathrm{a}}$ & $15.62^{\mathrm{a}}$ & $16.28^{\mathrm{a}}$ & 0.62 \\
\hline $\mathrm{C}_{18.26 \mathrm{cis}}$ & $3.42^{\mathrm{b}}$ & $4.24^{\mathrm{a}}$ & $3.21^{\mathrm{b}}$ & $0.34 *$ \\
\hline $\mathrm{C}_{20.1}$ & $0.97^{\mathrm{a}}$ & $0.38^{\mathrm{ab}}$ & $0.25^{\mathrm{b}}$ & $0.23^{*}$ \\
\hline $\mathrm{C}_{18.3}$ & $0.19^{\mathrm{a}}$ & $0.07^{\mathrm{b}}$ & $0.07^{\mathrm{b}}$ & $0.02 *$ \\
\hline $\mathrm{C}_{20.3}$ & $1.01^{\mathrm{a}}$ & $0.02^{\mathrm{c}}$ & $0.09^{\mathrm{b}}$ & $0.01 *$ \\
\hline $\mathrm{C}_{18.36}$ & $0.04^{\mathrm{c}}$ & $0.20^{\mathrm{a}}$ & $0.14^{\mathrm{b}}$ & $0.02 *$ \\
\hline $\mathrm{C}_{20}$ & $0.22^{\mathrm{b}}$ & $0.72^{\mathrm{a}}$ & $0.64^{\mathrm{a}}$ & $0.11 *$ \\
\hline Saturated & 74.32 & 76.45 & 77.01 & -- \\
\hline Un saturated & 25.68 & 23.55 & 22.99 & -- \\
\hline Short $\left(<\mathrm{C}_{14}\right)$ & $4.80^{\mathrm{b}}$ & $5.34^{\mathrm{a}}$ & $5.80^{\mathrm{a}}$ & $0.18^{*}$ \\
\hline Medium & $56.63^{\mathrm{a}}$ & $50.85^{\mathrm{b}}$ & $53.46^{\mathrm{ab}}$ & $1.90 *$ \\
\hline Long $\left(>C_{17}\right)$ & $38.53^{\mathrm{c}}$ & $43.78^{\mathrm{a}}$ & $40.76^{\mathrm{b}}$ & $0.72 *$ \\
\hline Sat/unsat & 2.89 & 3.25 & 3.35 & -- \\
\hline Total FA & 100 & 100 & 100 & -- \\
\hline
\end{tabular}

$T_{1}$ : Asperozym, $T_{2}$ : Tomoko, Each value is a mean of 3 composite samples from 9 animals, SE $=$ Standard error.

announced that total FFA content of Örgü (semi-hard white) Turkish cheese made from raw milk (RMC) remained constant until the day 30. He mentioned that there was no meaningful boost in total FFA content during ripening in pasteurized milk cheese (PMC). The main FFA observed in the raw and pasteurized milk Örgü cheeses during ripening were palmitic, oleic, myristic, steric and capric acids, representing together approximately $82 \%$ of total FFA content. Same trend was observed with Aminifar 


\section{Kholif et al.}

and Emam-Djomeh (2014) who displayed that short chain fatty acids had significantly increased in traditional Iranian cheese at different ratios of lipase. A similar observation was found by Abd El-Aziz et al. (2015) in milk fat produced from lactating buffaloes fed different rations supplemented with fibrolytic enzymes.

\section{Amino acids profile:}

With concerning impact of fibrolytic enzymes on amino acid profile of soft cheese samples. From Table (6) we could perceived that both of Asrozym and Tomoko enzymes had depressed results $(\mathrm{P}<0.05)$ in histidine, threonine, isoleucine, leucine, glycine, alanine and proline amino acids compared to control. While Tomoko enzyme raised $(\mathrm{P}<0.05)$ each of valine, methionine, phenylalanine and serine amino acids. Generally, total essential amino acids / total nonessential amino acids was significantly $(\mathrm{P}<0.05)$ increased in soft cheese with adding Tomoko enzyme to buffaloes diets. Actually, starter culture might had a great role in production of different concentrations of amino acids. Total concentration of free amino acids were significantly $(\mathrm{P}<0.05)$ unlike between different types of soft cheese. It was 3229.53 followed by 2777.51 then $2061.63\left(\mathrm{~g} / 100 \mathrm{~g}\right.$ sample) for control, $\mathrm{T}_{2}$ and $\mathrm{T}_{1}$. In the fact, these data were in accordance with chemical analysis in cheese samples which indicated high contents of SN/TN, tyrosine and tryptophan (proteolysis indicators) at the end of storage period.

Some authors explicated that FAA structure and concentration mostly counted on milk source, season, processing technology, existance of natural bacteria strains and other sources of enzymes, amount of fatty acids and ripening status and duration (Milesi et al. 2009 and Sihufe et al. 2010).

Another explanation from Eren-Vapur and Ozcan (2012) who stated that the prolong of lactic acid bacteria $(\mathrm{LAB})$ as a starter culture, produced a higher content of short-chain peptides and FAAs during cheese ripening. So, various starter bacteria liberate different levels of single FAA based on their enzyme system and the degree of autolysis in white Turkish cheese. The total concentration of FAAs increased during ripening and Phe, Leu - Ile, Gln, Pro, Ala and Val were the principal FAAs in the cheeses at all stages of ripening.

Table (6): Amino acids profile (g/100 $\mathrm{g}$ sample) of different types of white soft cheese samples at the end of experiment.

\begin{tabular}{|c|c|c|c|c|}
\hline Amino Acids & Control & $\mathrm{T}_{1}$ & $\mathrm{~T}_{2}$ & SE \\
\hline \multicolumn{5}{|l|}{ EAA } \\
\hline Histidine & $91.23^{\mathrm{a}}$ & $16.13^{\mathrm{c}}$ & $57.37^{\mathrm{b}}$ & $10 *$ \\
\hline Arginine & $251.68^{\mathrm{a}}$ & $153.15^{b}$ & $217.55^{\mathrm{a}}$ & $21^{*}$ \\
\hline Threonine & $89.67^{\mathrm{a}}$ & $15.46^{\mathrm{c}}$ & $34.07^{\mathrm{b}}$ & $9 *$ \\
\hline Valine & $93.50^{\mathrm{b}}$ & $144.23^{b}$ & $272.02^{\mathrm{a}}$ & $27 *$ \\
\hline Methionine & $537.43^{b}$ & $559.87^{b}$ & $647.15^{\mathrm{a}}$ & $30 *$ \\
\hline Isoleucine & $351.07^{\mathrm{a}}$ & $164.15^{b}$ & $207.02^{\mathrm{b}}$ & $19 *$ \\
\hline Luecine & $628.93^{\mathrm{a}}$ & $131.17^{\mathrm{c}}$ & $262.27^{\mathrm{b}}$ & $33^{*}$ \\
\hline Phenylala. & $172.70^{\mathrm{b}}$ & $157.55^{\mathrm{b}}$ & $364.80^{\mathrm{a}}$ & $18^{*}$ \\
\hline Lysine & $323.93^{\mathrm{b}}$ & $441.92^{\mathrm{a}}$ & $164.23^{c}$ & $31 *$ \\
\hline Total EAA & $2540.14^{\mathrm{a}}$ & $1626.64^{b}$ & $2226.43^{\mathrm{a}}$ & $164 *$ \\
\hline \multicolumn{5}{|l|}{ NEAA } \\
\hline Aspartic & $58.82^{\mathrm{a}}$ & $32.10^{\mathrm{a}}$ & $32.60^{\mathrm{a}}$ & 15 \\
\hline Glutamic & $90.25^{\mathrm{a}}$ & $42.23^{\mathrm{a}}$ & $69.30^{\mathrm{a}}$ & 21 \\
\hline Serine & $26.75^{\mathrm{b}}$ & $64.03^{\mathrm{b}}$ & $124.42^{\mathrm{a}}$ & $16^{*}$ \\
\hline Glycine & $49.00^{\mathrm{a}}$ & $13.17^{\mathrm{b}}$ & $7.35^{\mathrm{b}}$ & $7 *$ \\
\hline Alanine & $136.63^{\mathrm{a}}$ & $35.83^{\mathrm{b}}$ & $44.00^{\mathrm{b}}$ & $17 *$ \\
\hline Proline & $73.84^{\mathrm{a}}$ & $50.80^{\mathrm{ab}}$ & $38.78^{\mathrm{b}}$ & $12 *$ \\
\hline Tyrosine & $172.82^{\mathrm{a}}$ & $59.65^{\mathrm{b}}$ & $162.83^{\mathrm{a}}$ & $15^{*}$ \\
\hline Cystine & $81.28^{\mathrm{ab}}$ & $137.18^{\mathrm{a}}$ & $71.80^{\mathrm{b}}$ & $21^{*}$ \\
\hline TNEAA & $689.39^{\mathrm{a}}$ & $434.99^{\mathrm{b}}$ & $551.08^{\mathrm{ab}}$ & $72 *$ \\
\hline TAA & $3229.53^{\mathrm{a}}$ & $2061.63^{b}$ & $2777.51^{\mathrm{a}}$ & $224 *$ \\
\hline EAA/NEAA & $3.68^{\mathrm{b}}$ & $3.74^{\mathrm{b}}$ & $4.04^{\mathrm{a}}$ & $0.10^{*}$ \\
\hline
\end{tabular}

$T_{1}=$ Asperozym,$T_{2}=$ Tomoko, $S E=$ Standard error. Each value is a mean of 3 composite samples from 9 animals. 


\section{Sensory evaluation:}

Sensory arbitration is one of the most important estimation of any product success. Consumer must be satisfied of any product to buy it. Sensory evaluation of different soft cheese were cleared in Table (7). It was obvious that adding fibrolytic enzymes to animal diets did not significantly $(\mathrm{P}>0.05)$ affect of obtained cheese's flavor or sensory characteristics when fresh and after 30 days compared to control. Flavor of cheese is a collection of lipolysis and proteolysis which took place during storage period. As a matter of fact, proteolysis is one of the factors of cheese ripening which give the cheese its typical flavor and texture. Urbach (1995) clarified that flavors and aroma compounds are linked to amino acid metabolism. Flavor attributive and definition of threshold values of amino acids such as Gly, Ser, Thr, Ala and Pro amino acids have been suggested to have an influence on tastes.

While, lysis of Leu, Ile and Val results in the formation of isovaleric, 2-methylbutanoic and isobutyric acid respectively and they are responsible for cheesy, sweaty, sour, rancid or putrid odors (Poveda et al. 2004 and Ardö, 2006).

Table (7): Sensory evaluation of of different types of white soft cheese samples at fresh and after 30 days of storage period.

\begin{tabular}{lcccc}
\hline Item & Control & $\mathrm{T}_{1}$ & $\mathrm{~T}_{2}$ & $\mathrm{SE}$ \\
\hline Fresh flavor (50) & 45.2 & 46.6 & 46.27 & $0.49^{\mathrm{ns}}$ \\
Body \& Texture (40) & 33.07 & 35.93 & 35.33 & $1.43^{\mathrm{ns}}$ \\
Appearance (10) & 8.07 & 8.67 & 8.33 & $0.30^{\mathrm{ns}}$ \\
Total (100) & 86.33 & 91.2 & 89.93 & $2.18^{\mathrm{ns}}$ \\
30 Days flavor (50) & 45.25 & 45.75 & 46.33 & $0.49^{\mathrm{ns}}$ \\
Body \& Texture (40) & 36.75 & 37.25 & 37.33 & $1.43^{\mathrm{ns}}$ \\
Appearance (10) & 8.42 & 8.83 & 8.75 & $0.30^{\mathrm{ns}}$ \\
Total (100) & 90.42 & 91.83 & 92.42 & $2.18^{\mathrm{ns}}$ \\
\hline
\end{tabular}

$T_{1}=$ Asperozym , $T_{2}=$ Tomoko, $S E=$ Standard error. Each value is a mean of 15 referee on 9 samples.

\section{CONCLUSION}

Ultimately, we can concluded that, the two different types of fibrolytic enzymes which used in our study did not significantly affect the lactation performance of dairy buffaloes except $4 \%$ fat corrected milk. Likewise, soft cheese samples had like characteristics in both types compare to control. We can also advised that using of the Egyptian enzyme is similar to importer enzyme in some parameters. So, we can save hard currency that spent on procurement.

\section{ACKNOWLEDGMENT}

The authors acknowledge National Research Centre, 33 Bohouth Street, Dokki, Giza, Egypt for supporting this work.

\section{REFERENCES}

Abdel-Aziz NA, Salem AZM, El-Adawy MM, Camacho LM, Kholif AE, Elghandour MMY, Borhami BE. (2015). Biological treatments as a mean to improve feed utilization in agriculture animals: An overview. J Integr Agr.; 14(3): 534-543.

Abdel Razig, A.K. (1996). Production of white soft cheese from different milk sources. M.Sc. Thesis, University of Khartoum, Sudan.

ADSA. (1987). Score Card for Cheese. American Dairy Science Association. Champaign, TL. P. 84. 


\section{Kholif et al.}

Alsersy, H.; Salem, A. Z. M.; Borhami, B. E.; Olivares, J.; Gado, H. M.; Mariezcurrena, M. D.; Yacuot, M. H.; Kholif, A. E.; El-Adawy, M. and Hernandez, S. R. (2015). Effect of Mediterranean saltbush (Atriplex halimus) ensilaging with two developed enzyme cocktails on feed intake, nutrient digestibility and ruminal fermentation in sheep. Anim Sci J.; 86: 51- 58.

Aminifar, M. and Emam-Djomeh, Z. (2014). Changes of Texture, Microstructure and Free Fatty Acid Contents of Lighvan Cheese during Accelerated Ripening with Lipase. J. Agr. Sci. Tech. Vol. 16: 113-123.

AOAC (1995). Official Methods of Analysis of AOAC International. 16th Edn., Vol. 1, AOAC, Washington, DC., USA.

AOAC (2007). Association of Official Analytical Chemists. Official Methods of Analysis, 19th Ed. Washington, DC, USA.

Ardö, Y. (2006). Flavor formation by amino acid catabolism, Biotechnology Advances 24 (2), 238-242.

Azzaz, H.H., A.M. Kholif, H.A. Murad, M.A. Hanfy and M.H. Abdel Gawad (2012). Utilization of cellulolytic enzymes to improve the nutritive value of banana wastes and performance of lactating goats. Asian J. Anim. Vet. Adv., 7: 664-673.

Beauchemin, K.A., L.M. Rode, M. Maekawa, D.P. Morgavi and R. Kampen (2000). Evaluation of a nonstarch polysaccharidase feed enzyme in dairy cow diets. J. Dairy Sci., 83: 543-553.

Bielecki, S.; A. Krystynowicz; M. Turkiewicz and H. Kalinowska (2005). Bacterial cellulose. Biopolymers online. http://onlinelibrary.wiley.com/.

Bowman, G.R., K.A. Beauchemin and J.A. Shelford (2002). The proportion of the diet to which fibrolytic enzymes are added affects nutrient digestion by lactating dairy cows. J. Dairy Sci., 85: 3420-3429.

Chen, K.H., J.T. Huber, J. Simas, C.B. Theurer and P. Yu et al., (1995). Effect of enzyme treatment or steam-flaking of sorghum grain on lactation and digestion in dairy cows. J. Dairy Sci., 78: 1721-1727.

Delgado, F. J.; 'lez-Crespo, J. G.; Ladero, L.; Cava, R. and Ramı 'rez, R.(2009). Free fatty acids and oxidative changes of a Spanish soft cheese (PDO 'Torta del Casar') during ripening. International Journal of Food Science and Technology, 44, 1721-1728.

Duncan, D.B. (1955). Multiple range and multiple F tests. Biometrics, 11: 1-42.

Elghandour, M.M.Y.; A.Z.M. Salem; J.S. Martínez Castañeda; L.M. Camacho; A.E. Kholif and J.C. Vázquez Chagoyán (2015). Direct fed microbes: A tool for improving the utilization of low quality roughages in ruminants. J. Integr. Agr.; 14(3): 526-533.

El-Owni, O.A. and O.I. Hamid (2008). Effect of storage period on wight loss, chemical composition, microbiloigical and sensory characteristics of Sudanese white cheese (Gibna Bayeda ). Paks. J. Nutr. $7: 75-80$

El-Owni, O.A.O. and O.I.A. Hamed (2007). Production of White Cheese (Gibna bayda) in Zalingei Area West Darfur (Sudan). Australian Journal of Basic and Applied Sciences, 1(4): 756-762.

Elwakeel, E.A., E.C. Titgemeyer, B.J. Johnson, C.K. Armendariz and J.E. Shirley (2007). Fibrolytic enzymes to increase the nutritive value of dairy feedstuffs. J. Dairy Sci., 90: 5226-5236.

Eren-Vapur, U. and T. Ozcan (2012). Determination of free amino acids in whole-fat Turkish White Brined Cheese produced by animal and microbial milk-clotting enzymes with and without the addition of starter culture. Mljekarstvo 62 (4), 241-250.

Fahmi, A.H. and H.A. Sharara (1950). Studies on Egyptian Domiati cheese. J. Dairy Res; 17: 312.

Fenelon, M. A. and T.P. Guinee (2000). Flavour development in low fat cheese. In: Cogan T M, Mc Sweeney PLH, Guinee T P. Proceedings of sixth Moorpark cheese symposium. Dublin: Teagasc.; $31-$ 42.

Fox, P.F.; T.P. Guinee; T.M. Cogan and P.L.H. McSweeney (2000). Fundamentals of Cheese Science. Aspen Publishers, Inc. Gaithersburg, Maryland.

Gado, H.M., H.M. Metwally, A.Z. El-Basiony, H.S. Soliman and E.R.I. Abd El Galil (2007). Effect of biological treatments on sugarcane bagasse digestibility and performance of Baldi goats. Egypt. J. Nutr. Feeds, 10: 535-551. 
Gado, H.M., A.Z.M. Salem, P.H. Robinson and M. Hassan (2009). Influence of exogenous enzymes on nutrient digestibility, extent of ruminal fermentation as well as milk production and composition in dairy cows. Anim. Feed Sci. Technol., 154: 36-46.

Giraldo, L.A.; M.L. Tejido; M.J. Ranilla and M.D. Carro (2008). Effects of exogenous fibrolytic enzymes on in vitro ruminal fermentation of substrates with different forage: Concentrate ratios. Anim Feed Sci Technol; 141: 306-325.

Hamid, O.I.A. (2005). Effect of storage period on weight loss, chemical composition, microbiological proprieties of white soft cheese .Ph.D Thesis . University of Khartoum Sudan.

Hayaloglu, A.A.; M. Guven and P.F. Fox (2002). Microbiological, biochemical and technological properties of Turkish white cheese "Beyaz Peynir". Inter. Dairy J., 12: 635-648.

Herrington, B.L. (2000). Milk and Milk Processing. Published by Green world Publisher, New Delhi, India.

Khattab, H.M.; H.M. Gado; A.E. Kholif; A.M. Mansour and A.M. Kholif (2011). The potential of feeding goats sun dried rumen contents with or without bacterial inoculums as replacement for berseem clover and the effects on milk production and animal health. Inter J Dairy Sci.; 6: 267-277.

Kholif, A.M.; M. Abd El-Aziz; M.H. El-Senaity; M.A. Abd El-Gawad. And A.F. Sayed (2015). Effect of Diet Supplemented with Cellulase Enzymes on Lactating Goats Performance, and Milk and Cheese Properties. Life Science Journal 12/2015; 12(2s):16-22.

Kholif, A.M. and H.A. Aziz (2014). Influence of feeding cellulytic enzymes on performance, digestibility and ruminal fermentation in goats. Anim Nutr Feed Technol., 14: 121-136.

Kholif, A.M.; M.A.M. Abd El-Gawad and S.M. Kholif (2010). Properties of Mozzarella cheese from milk of goats fed diets supplemented with caraway or Lepidium sativum seeds. Egypt. J. Nutr. and Feeds, 13: 193-204.

Kholif, A.M.; M.H. El-Senaity; M.A. Abd El-Gawad and M.M. El-Sayed (2009). Effect of supplementing diets with functional additives on the resultant milk and cheese of Baladi cows. Egypt. J. Nutr. Feeds, 12: 143-152.

Kholif, S.M.; H. Gado; T.A. Morsy; N. El-Bordeny and A.A. Abedo (2012). Influence of exogenous enzymes on nutrient digestibility, blood composition, milk production and its composition as well as milk fatty acids profile in dairy buffaloes. Egypt. J. Nutr. Feeds, 15: 13-22.

Knowlton, K.F.; J.M. McKinney and C. Cobb (2002). Effect of a direct-fed fibrolytic enzyme formulation on nutrient intake, partitioning and excretion in early and late lactation Holstein cows. J. Dairy Sci., 85: 3328-3335.

Krueger, N.A. and A.T. Adesogan (2008). Effect of different mixtures of fibrolytic enzymes on the digestion and fermentation of bahiagrass hay. Anim Feed Sci Technol; 145: 84-94.

Law, B., (1999). Technology of Cheese making. Sheffield Academic Press, Sheffield, UK.

Mandels, M.; L. Hontz and J. Nystrom (1974). Enzymatic hydrolysis of waste cellulose. Biotechnol. Bioeng., 16: 1471-1493.

Milesi, M.M.; G. Vinderola; N. Sabbag; C.A. Meinardi and E. Hynes (2009). Influence on cheese proteolysis and sensory characteristics of non-starter lactobacilli strains with probiotic potential, Food Research International 42 (8), 1186-1196.

Miller, G.L. (1972). Use of dinitrosalicyclic acid reagent for determination of reducing sugar. Biotechnol. Bioeng., 5: 193-219.

Morgavi, D.P.; K.A. Beauchemin; V.L. Nsereko; L.M. Rode and A.D. Iwaasa (2000). Synergy between ruminal fibrolytic enzymes and enzymes from Trichoderma longibrachiatum. J. Dairy Sci., 83: 13101321.

Msimango, N.N.P. and F.N. Fon (2016). Monitoring the fibrolytic potential of microbial ecosystems from domestic and wild ruminants browsing tanniferous forages. Animal Nutrition 2: 40-44.

Mustafa, W.A.; A.E. Sulieman; W.S. Abdelgadir and E.A. Elkhalifa (2013). Chemical Composition of the White Cheese Produced at Household Level in Dueim Area, White Nile State, Sudan. J. Food Nutr Disor, 2:2. 


\section{Kholif et al.}

Natsir, A. (2012). Fibre utilization by ruminants, vol. 2. p. 1e188. http://repository. unhas.ac.id/.

Nsereko, V.L.; K.A. Beauchemin; D.P. Morgavi; L.M. Rode and A.F. Furtado (2002). Effect of a fibrolytic enzyme preparation from Trichoderma longibrachiatum on the rumen microbial population of dairy cows. Can. J. Microbiol., 48: 14-20.

Nsereko, V.L.; D.P. Morgavi; L.M. Rode; K.A. Beauchemin and T.A. McAllister (2000). Effects of fungal enzyme preparations on hydrolysis and subsequent degradation of alfalfa hay fiber by mixed rumen microorganisms in vitro. Anim. Feed Sci. Technol., 88: 153-170.

Poveda, J.M., L. Cabezas and P.L.H. McSweeney (2004). Free amino acid content of Manchego cheese manufactured with different starter cultures and changes throughout ripening, Food Chemistry 84 (2), 213-218.

Reddish, M.A. and L. Kung Jr. (2007). The effect of feeding a dry enzyme mixture with fibrolytic activity on the performance of lactating cows and digestibility of a diet for sheep. J. Dairy Sci., 90: 4724-4729.

Rodrigues, M.A.M.; P. Pinto; R.M.F Bezerra; A.A. Dias and C.V.M. Guedes (2008). Effect of enzyme extracts isolated from white-rot fungi on chemical composition and in vitro digestibility of wheat straw. Anim. Feed Sci. Technol., 141: 326-338.

Salem, A.Z.M.; H.M. Gado; D. Colombatto and M.M.Y. Eghandour (2013). Effect of exogenous enzymes on nutrient digestibility, ruminal fermentation and growth performance in beef steers. Livest Sci.; 154: 69-73.

SAS. (2004). Statistical Analysis System. SAS User's Guide Statistics. SAS Institute Inc. Editors, Cary, $\mathrm{NC}$.

Schingoethe, D.J.; G.A. Stegeman and R.J. Treacher (1999). Response of lactating dairy cows to a cellulase and xylanase enzyme mixture applied to forages at the time of feeding. J. Dairy Sci., 82: 996-1003.

Sihufe, G.A.; S.E. Zorrilla and A.C. Rubiolo (2010). The influence of ripening temperature and sampling site on the proteolysis in the Reggianito Argentino cheese, LWTFood Science Technology 43 (2), 247-253.

Soares, M.M.C.N., R. da Silva and E. Gomes (1999). Screening of bacterial strains for pectinolytic activity characterization of the pgase produced by Bacillus species. Rev. Microbiol., 30: 299-303.

Stella, A.V.; R. Paratte; L. Valnegri; G. Cigalino; G. Soncini; E. Chevaux; V. Dell'Orto and G. Savoini (2007). Effect of administration of live Saccharomyces cerevisiae on milk production, milk composition, blood metabolites, and faecal flora in early lactating dairy goats. Small Ruminant Res.; 67: 7-13.

Titi, H.H. (2003). Evaluation of Feeding a Fibrolytic Enzyme to Lactating Dairy Cows on Their Lactational Performance during Early Lactation. Asian-Aust. J. Anim. Sci., vol. 16, No. 5 :677-684.

Titi, H.. and W. Lubbadeh (2004). Effect of feeding cellulase enzyme on productive responses of pregnant and lactating ewes and goats. J. Small Ruminant Res 2004; 52: 137-143.

Tricarico, J.M.; J.D. Johnston; K.A. Dawson; K.C. Hanson; K.R. McLeod and D.L. Harmon (2005). The effects of an Aspergillus oryzaeextract containing alpha-amylase activity on ruminal fermentation and milk production in lactating Holstein cows. Anim. Sci., 81: 365-374.

Türkoğlu, H. (2011). Free fatty acid composition and sensory characteristics of Örgü cheese. Scientific Research and Essays, vol. 6(7), pp. 1555-1560, 4 April.

Urbach, G. (1995). Contribution of lactic acid bacteria to flavor compound formation in dairy products, International Dairy Journal 5 (8), 877-903.

Valdes, K.I.; A.Z.M. Salem; S. Lopez; M.U. Alonso; N. Rivero; M.M.Y. Elghandour; I.A. Domínguez; M.G. Ronquillo and A.E. Kholif (2015). Influence of exogenous enzymes in presence of Salix babylonica extract on digestibility, microbial protein synthesis and performance of lambs fed maize silage. J Agr Sci Camb; doi. 10.1017/S0021859614000975.

Van Soest, P.J.; J.B. Robertson and B.A. Lewis (1991). Methods for dietary fiber, neutral detergent fiber and nonstarch polysaccharides in relation to animal nutrition. J. Dairy Sci., 74: 3583-3597. 
Walstra, P.; H.J.M. Van Dijk and T.J. Gerurts (1987). The synereies of curd. In cheese physics and microbiology, p. 135-179. Fox p.f., ed. New York. Elsevier Applied science .

Yang, W.Z.; K.A. Beauchemin and L.M. Rode (1999). Effects of an enzyme feed additive on extent of digestion and milk production of lactating dairy cows. J. Dairy Sci., 82: 391-403.

Zheng, W.; D.J. Schingoethe; G.A. Stegeman; A.R. Hippen and R.J. Treacher (2000). Determination of when during the lactation cycle to start feeding a cellulase and xylanase enzyme mixture to dairy cows. J. Dairy Sci., 83: 2319-2325.

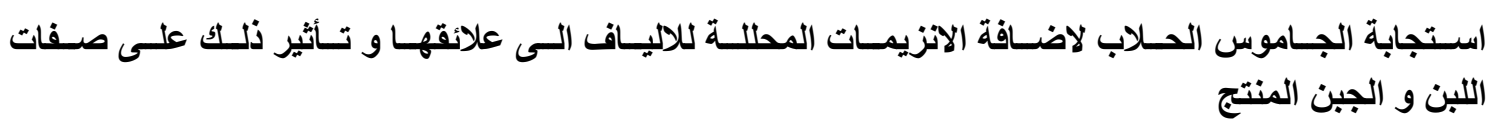

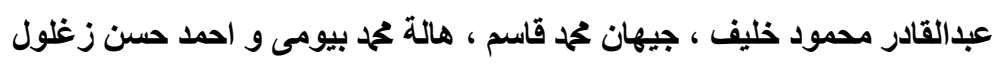

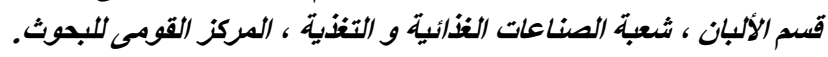

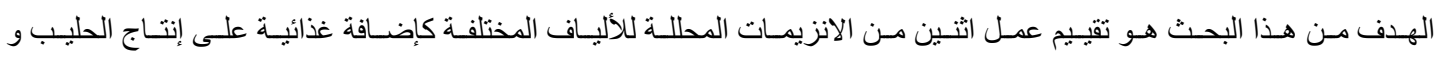

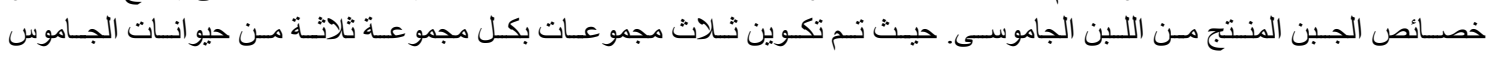

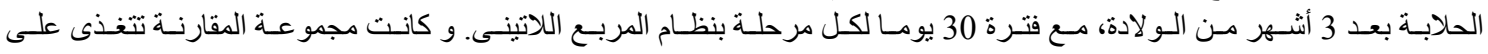

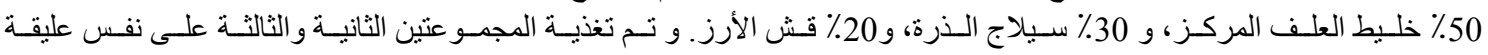

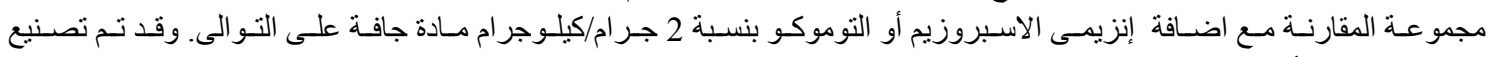

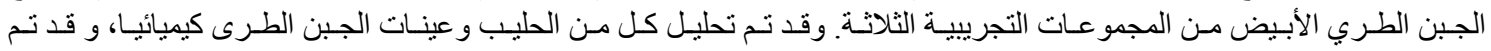

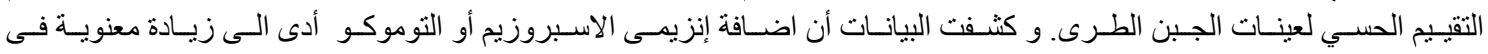

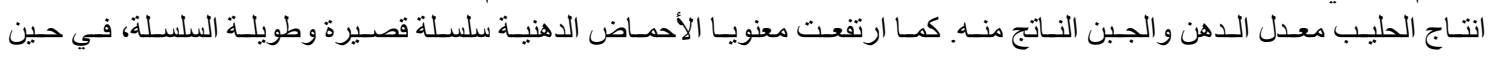

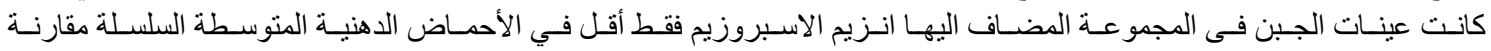

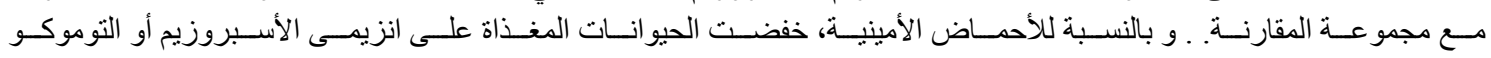

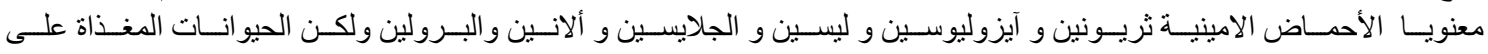

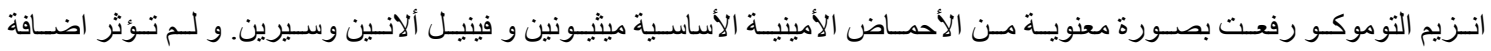

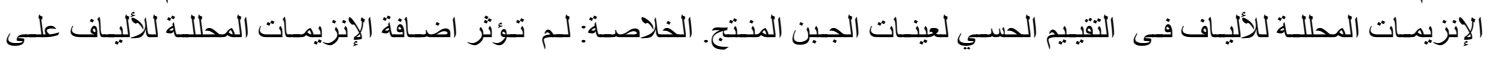

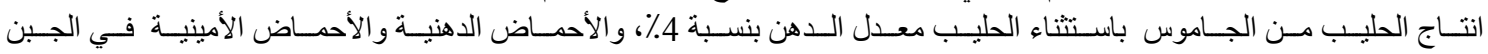

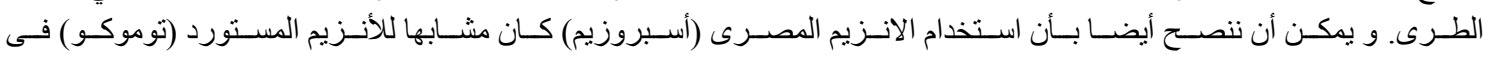

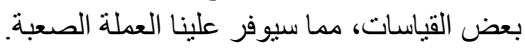
كلمات مفتاحية: الإنزيمات المحللة للألياف، إنتاج الحليب الجاموسى، الجبن الطري الأبيض، والأحماض الدهنية و الأمينية. 